\title{
Genetic divergence detected by ISSR markers and characterization of microsatellite regions in Mytilus mussels ${ }^{\mathrm{i}}$
}

\author{
Miguel A. Varela, Ana González-Tizón, Luis Mariñas, Andrés Martínez-Lage ${ }^{\mathrm{ii}}$ \\ Departamento de Biología Celular y Molecular, Facultade de Ciencias, Universidade da Coruña, Coruña, Spain
}

Biochemical Genetics, volume 45, issue 7-8, pages 565-578, August 2007

Received 14 December 2006, accepted 12 March 2007, first published 05 June 2007

\section{How to cite:}

Genetic divergence detected by ISSR markers and characterization of microsatellite regions in Mytilus mussels. Miguel A. Varela, Ana González-Tizón, Luis Mariñas, Andrés Martínez-Lage, Biochem. Genet. (2007), 45(7-8): 565-578. DOI 10.1007/s10528-007-9097-7

\begin{abstract}
The wide distribution of microsatellites in mussels of the Mytilus edulis complex (Mytilidae) enables the analysis of inter-simple-sequence repeat (ISSR) markers. The aim of this investigation was to assess genetic differentiation in six sampling localities distributed along the European Atlantic coast to expose the potential of these markers in genetic studies requiring the detection of low polymorphism and as a source of sequences for developing microsatellite markers. We detected low genetic structuring within each member of the Mytilus edulis complex. Nei and Li distances and AMOVA clustered the individuals studied into two groups. On the basis of these results two sampling localities coming from the M. edulis $\times$ M. galloprovincialis mosaic hybrid zone in Western Europe were assigned to one species. On the other hand, mussels of a sampling locality in the Baltic Sea were not significantly different from a pure M. edulis locality supporting an extensive introgression of M. edulis in these individuals. Finally, 148 microsatellites were found in the sequences of 51 ISSR markers, and two polymorphic microsatellite markers were developed.
\end{abstract}

Keywords: Genetic variation; ISSR; microsatellite; mussel; Mytilus

\section{Introduction}

Choosing an effective method to assess genetic variability in a group of individuals is of great interest to many researchers studying population genetics. In recent years, different molecular markers based on PCR amplification have been developed and rapidly have become essential tools in this field. Some of these markers are microsatellite-based, such as the inter-simple sequence repeat (ISSR) markers (Zietkiewicz et al. 1994). ISSR markers are generated from nucleotide sequences located between two microsatellite priming sites inversely oriented on opposite DNA strands and near enough to be amplified by PCR (Fig. 1). This technique relies on the high polymorphism and wide distribution of microsatellites to detect low differentiation levels. Prior knowledge of the sequence is not needed, and numerous polymorphic bands are generated. Like other dominant markers, such as RAPDs, the ISSR amplification products are scored as present or absent without distinguishing between heterozygous and dominant homozygous. ISSR markers, however, have more stringent primer annealing conditions than RAPDs, which leads to higher reproducibility. Those features, along with the ease and cost, have brought attention to these markers. 


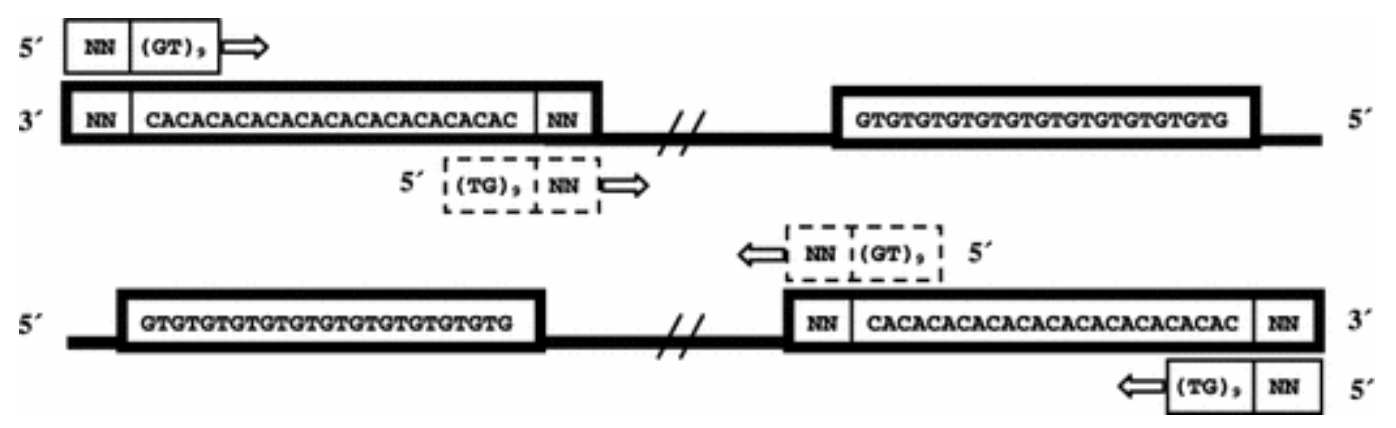

Figure 1. Structure of ISSR markers and annealing of anchored primers. Diagonal lines separate microsatellite priming sites inversely oriented on opposite DNA strands and near enough to be amplified by PCR. Dotted-line rectangles represent $3^{\prime}$ anchored primers, and small solid-line rectangles represent 5' anchored primers. Arrows indicate direction of DNA polymerization $\left(5^{\prime}-3^{\prime}\right)$. $\mathrm{N}$ represents an anchoring nucleotide

Research using ISSR markers has focused on evaluating genetic variation in terrestrial ecosystems. Less attention has been paid to the application of these markers in marine populations, where they have been used to evaluate the gene flow of two teleost species between the Red Sea and the Mediterranean (Hassan et al. 2003) and to detect a fine-scale genetic structure in the bivalve Gemma gemma (Casu et al. 2005). In the marine environment, natural borders between populations are less evident than in terrestrial ecosystems. In the case of Mytilus spp., the broad distribution, external fertilization, high fecundity, planktonic larval stage, and existence of hybrid zones between sibling species hinder the definition of population structure, the distribution limit of each species, and the parentage of a particular individual (Koehn 1991; Palumbi 1994). Different techniques have been applied to study genetic differentiation in the Mytilus edulis complex (a hybrid complex including M. edulis, M. galloprovincialis, and M. trossulus), but to date no ISSR studies have been published on this complex. The purposes of this study were, first, to study the pattern of genetic variation in the complex Mytilus edulis in several localities of the European Atlantic coast to expose the potential of these markers in genetic studies requiring the detection of low polymorphism; and second, to examine the suitability of ISSR markers as a source of sequences for developing microsatellite markers in these bivalves.

\section{Materials and Methods}

\section{$\underline{\text { Sample Collection and DNA Extraction }}$}

The analysis of ISSR markers was performed on 120 Mytilus individuals from the European Atlantic coast. Mussels were obtained from the intertidal areas of Balcobo, Isle of Batz, Isle of Man, and Öland Island, and cultured mussels from Arousa and Yerseke. DNA was extracted as described by Winnepenninck et al. (1993) from $25 \mathrm{mg}$ of adductor muscles and mantle. Samples stored in ethanol were rehydrated in PBS $(0.137 \mathrm{M}$ $\left.\mathrm{NaCl}, 2.68 \mathrm{mM} \mathrm{KCl}, 10.1 \mathrm{mM} \mathrm{Na}_{2} \mathrm{HPO}_{4}, 1.76 \mathrm{mM} \mathrm{KH}_{2} \mathrm{PO}_{4}\right)$ and distilled water before DNA extraction. The geographic situation and number of individuals from each sampling locality are indicated in Fig. 2. 


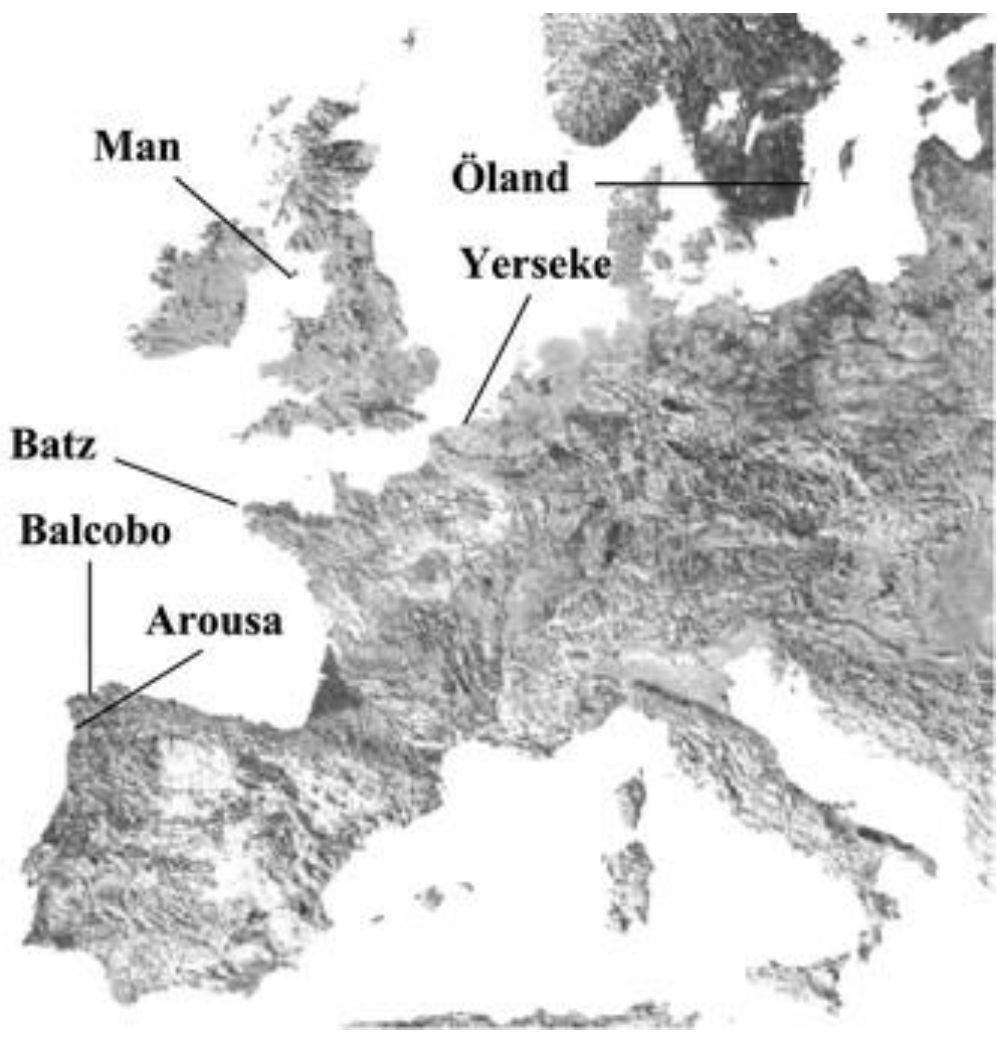

Figure 2. Geographic situation of each sampling locality. Sample sizes: Balcobo 22, Arousa 19, Isle of Batz 22, Yerseke 20, Isle of Man 18, Öland Island 19

Results obtained by Hummel et al. (2001) allowed us to identify the specimens from Yerseke as M. edulis, and individuals from Arousa and Balcobo were identified as M. galloprovincialis (Sanjuan et al. 1990). Baltic Sea mussels are considered hybrids M. trossulus $\times$ M. edulis as in Riginos and Cunningham (2005), who found that $96 \%$ of Baltic Sea mussels were hybrids. Finally, samples coming from the Isle of Batz and the Isle of Man could include M. galloprovincialis, M. edulis, or hybrids of both species, as both islands may be located in a mosaic hybrid zone (Bierne et al. 2003).

\section{$\underline{\text { PCR amplification }}$}

Each PCR reaction of ISSR markers had a final volume of $25 \mu$, containing $20 \mathrm{ng}$ of DNA template, $1 \times$ PCR buffer $\left(16 \mathrm{mM}\left(\mathrm{NH}_{4}\right)_{2} \mathrm{SO}_{4} ; 67 \mathrm{mM}\right.$ Tris-HCl, $\mathrm{pH}$ 8.8; 0.1\% Tween-20), $1 \mu \mathrm{M}$ primer, $0.2 \mathrm{mM}$ each dNTP, $5.2 \mathrm{mM} \mathrm{Mg} 2 \mathrm{Cl}$, and $0.75 \mathrm{U}$ Taq DNA polymerase (Bioline). Amplifications were performed using a Touchdown PCR (Don et al. 1991) in a PTC-100 thermal cycler under the following conditions: $94^{\circ} \mathrm{C} 2 \mathrm{~min}$, $94^{\circ} \mathrm{C} 20 \mathrm{~s}, 66^{\circ} \mathrm{C} 30 \mathrm{~s}, 72^{\circ} \mathrm{C} 2 \mathrm{~min}$, and the annealing temperature was dropped $1^{\circ} \mathrm{C}$ for each of the subsequent 10 cycles followed by 30 cycles at $94^{\circ} \mathrm{C} 20 \mathrm{~s}, 55^{\circ} \mathrm{C} 30 \mathrm{~s}$, and $72^{\circ} \mathrm{C} 2 \mathrm{~min}$, with a final extension at $72^{\circ} \mathrm{C} 5 \mathrm{~min}$. Primer ISSR-23 (Table 1) required a higher final annealing temperature, and as a result, only 6 step-down cycles were needed, and the annealing temperature was kept at $59^{\circ} \mathrm{C}$ for 36 cycles.

Table 1. ISSR primers used to analyze the Mytilus genome

\begin{tabular}{llll}
\hline Primer & Sequence $^{\mathbf{a}}$ & Bands (bp) & Rp index $^{\mathbf{b}}$ \\
ISSR-23 & $5^{\prime}-\mathrm{YG}(\mathrm{CA})_{9}-3^{\prime}$ & $725,475,250$ & 1.59 \\
ISSR-21 & $5^{\prime}-\mathrm{YG}(\mathrm{GA})_{9}$-3 $^{\prime}$ & $1200,1050,950,400$ & 2.65 \\
ISSR-18 & $5^{\prime}-\mathrm{GATC}(\mathrm{CAG})_{7}-3^{\prime}$ & $1425,1275,1050,950,725$ & 3.13 \\
ISSR-16 & $5^{\prime}-\mathrm{YG}(\mathrm{CT})_{9}-3^{\prime}$ & $1500,1350,1250,900,850$ & 3.21 \\
ISSR-13 & $5^{\prime}-\mathrm{HVH}(\mathrm{TTCG})_{4}$-3 $^{\prime}$ & $1250,950,750,625$ & 2.84 \\
\hline
\end{tabular}

${ }^{\mathrm{a}} \mathrm{H}: \mathrm{A}, \mathrm{T}$, or $\mathrm{C} ; \mathrm{V}: \mathrm{C}, \mathrm{G}$, or A; Y: C or T

${ }^{\mathrm{b}} \mathrm{Rp}$ : resolving power

Microsatellite loci subsequently discovered within ISSR markers (see below) were characterized in 22 mussels (M. galloprovincialis) from Balcobo, located on the Atlantic coast of Spain. Microsatellite fragments were amplified with the following conditions: $94^{\circ} \mathrm{C} 2 \mathrm{~min}$, followed by 30 cycles of $92^{\circ} \mathrm{C} 1 \mathrm{~min}$, $\mathrm{T}_{\mathrm{a}} 1 \mathrm{~min}$, and $72^{\circ} \mathrm{C} 30 \mathrm{~s}$ with a final extension step at $72^{\circ} \mathrm{C} 10 \mathrm{~min}$. PCR reactions were carried out in a total 
volume of $25 \mu$ l consisting of $20 \mathrm{ng}$ DNA template, $1 \times$ Roche Taq PCR buffer (10 mM Tris-HCl, $\mathrm{pH} 8.3 ; 50$ $\mathrm{mM} \mathrm{KCl}$ ), $0.2 \mu \mathrm{M}$ each forward and reverse primers, $0.2 \mathrm{mM}$ each $\mathrm{dNTP}, 1.5 \mathrm{mM} \mathrm{MgCl}_{2}$, and $0.75 \mathrm{U}$ Taq DNA polymerase (Roche).

\section{Electrophoresis and Band Scoring}

Products obtained by DNA extraction and amplification of ISSR markers were observed on $1.5 \%$ agarose gels stained with ethidium bromide using the UVP Gelworks densitometry software, which quantifies DNA and assigns a fragment size to each band by scoring against a molecular weight marker (Roche $100 \mathrm{bp}$ ladder). Distinct and reproducible bands were scored present (1) or absent (0), and a binary matrix was constructed. A negative control was added in each run to test for contamination. To choose scorable bands and ensure reproducibility, a group consisting of four samples of each locality was amplified and analyzed twice. Microsatellite markers were evaluated for consistent amplification and polymorphism using an Agilent 2100 Electrophoresis Bioanalyzer (Agilent Technologies) (Panaro et al. 2000).

\section{$\underline{\text { Cloning }}$}

Pools of ISSR markers obtained by PCR were ligated into plasmid PCR2.1 Topo TA vector, used to transform Escherichia coli $\mathrm{TOP} 10 \mathrm{~F}^{\prime}$ competent cells (Invitrogen). Recombinant clones were selected as white colonies on ampicillin plates containing X-gal and IPTG. Inserts were sequenced using a capillary array electrophoresis sequencer CEQ 8000 Genetic Analysis System (Beckman Coulter).

\section{$\underline{\text { Data Analysis }}$}

The usefulness of ISSR markers, as fingerprinting of the banding pattern obtained with each primer, was evaluated using the Rp index of Prevost and Wilkinson (1999), who found a strong relationship between this index and the ability of a primer to differentiate between individuals. The Rp of a primer is $\mathrm{Rp}=\sum \mathrm{Ib}$, where $\mathrm{Ib}$ (band informativeness) is equal to $1-[2 \times(0.5-\mathrm{p})]$, $\mathrm{p}$ being the proportion of individuals containing this band. This index could be helpful as a primer choice-criterion to perform fingerprinting analyses in a particular species. The value of this index for each primer does depend on the number of individuals. For these values to be comparable among different studies, however, the groups considered must have similar levels of genetic diversity and the studies must apply the same analytical procedure.

Differentiation measures were first calculated without considering the absence of a given band in two individuals to be due to an identical ancestral mutation and without assuming Hardy-Weinberg equilibrium. Nei and Li (1979) distances for all pairwise individuals were calculated from the binary matrix using the software RAPDplot 3.0 (Black 1998). The estimates of intergroup distances corrected for intraspecific variation were obtained as $D^{\prime}{ }_{i j}=D_{i j}-\left[\left(n_{i}-1\right) D_{i}+\left(n_{j}-1\right) D_{j}\right] /\left(n_{i}+n_{j}-2\right)$, where $D_{i}$ and $D_{j}$ are the average distance in each group, $D_{i j}$ is the average distance in all pairwise individual comparisons between groups $\mathrm{i}$ and $\mathrm{j}$, and $n_{j}$ and $n_{i}$ are the number of individuals in each group (Kostia et al. 2000). The intergroup distance estimates were used to construct a neighbor-joining (NJ) tree. A principal coordinates analysis (PCA) was performed in SPSS 10.0.6 (SPSS Inc. 1999) using the Nei and Li distances (1979) generated between all pairs of individuals to determine how individuals from all localities cluster together.

The genetic structure was investigated using an AMOVA. The AMOVA analysis was carried out from a squared Euclidean distance matrix based on the binary matrix using the software Arlequin 2.0 (Schneider et al. 2000) to reveal the haplotypic diversity within localities, among localities, and among groups of localities.

To identify microsatellites in the ISSR markers, their sequences were analyzed with the program Tandem Repeats Finder 2.02 (TRF) (Benson 1999). This program uses an algorithm that finds simple sequences without requiring previous knowledge of the motif or size of the repetition unit. The search criteria were set 
with default parameters and 20 as the minimum alignment score. Oligo 6.3 (Molecular Biology Insights) was used for designing primers to amplify microsatellites with enough flanking sequence.

\section{Results}

Anchored primers generated polymorphic banding patterns in Mytilus (Fig. 3). Five out of $243^{\prime}$ and $5^{\prime}$ anchored primers were selected according to clarity and reproducibility criteria (Table 1). Little variation was observed between the replicate band profiles, except for a few large $(>1,500 \mathrm{bp})$ bands that were not reproducible. We selected 21 unambiguously scorable and reproducible markers. According to the Rp index, the primer ISSR-16 is the most appropriate to differentiate individuals, and a $250 \mathrm{bp}$ band obtained with the primer ISSR-23 is the most useful to differentiate sampling localities (Table 1). This band was fixed in the Isle of Batz and near fixation in Balcobo (0.86) and Arousa (0.89), but in Yerseke, Isle of Man, and Öland Island it appeared in low frequency $(0.10,0.17$, and 0.11 , respectively).

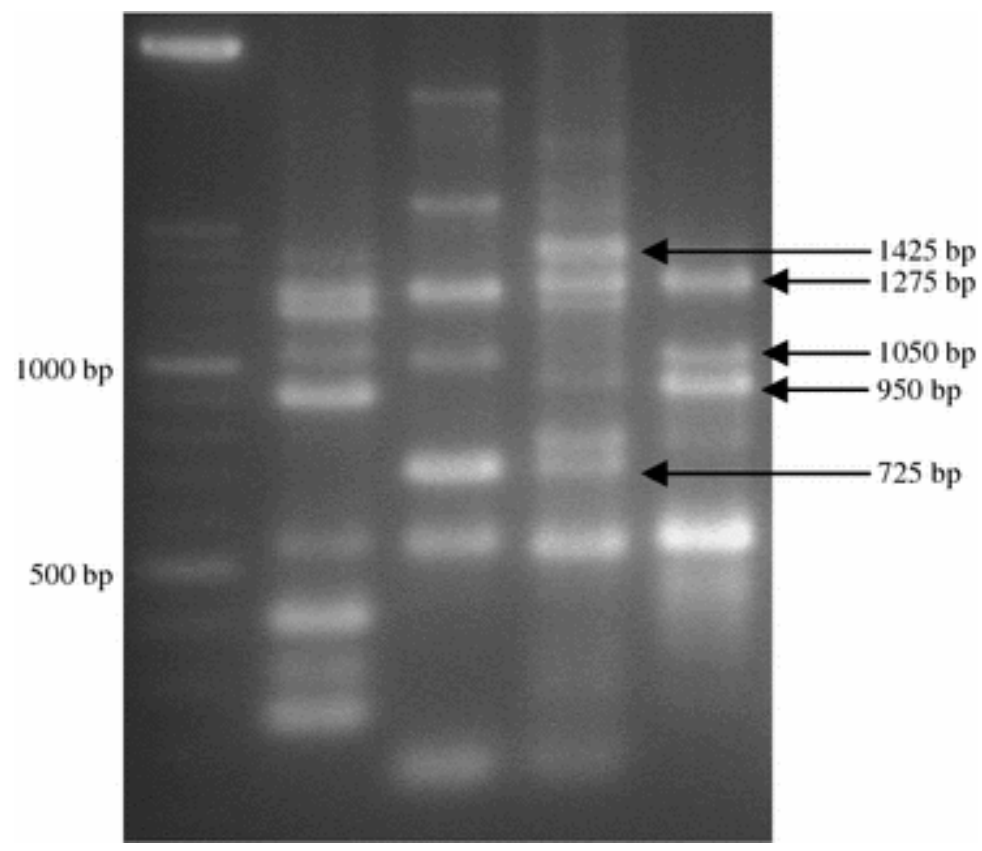

Figure 3. ISSR markers generated using the primer ISSR-18 with four M. galloprovincialis from Arousa. Sizes of selected bands are indicated on the right. The first lane contains a 100 bp ladder (DNA Molecular Weight Marker XIV, Roche)

An AMOVA was conducted on the binary matrix to appreciate the haplotypic diversity between groups of localities, between localities within groups, and within localities. Different preassigned structures were established, but it was the grouping (Balcobo, Arousa, Isle of Batz)/(Yerseke, Isle of Man, Öland Island) that displayed the higher proportion of variance between groups $\left(13.24 \%, \Phi_{C T}=0.161\right)$. Very little of the variation was attributed to the locality $\left(2.83 \%, \Phi_{S C}=\right.$ $0.033)$, and most of the variance appeared within localities $\left(83.92 \%, \Phi_{S T}=0.132\right)$. The variance components were significant $(P<0.001)$ within each locality and between groups, showing the existence of heterogeneity at these levels. The variance calculated among localities of the same group suggests the existence of low genetic structuring $\left(\Phi_{S C}=0.033, P=0.011\right.$ ), using a null distribution computed by 1,000 permutations.

Locality clustering was performed from Nei and Li distances using the NJ method included in the software package Phylip 3.5c (Felsenstein 1993). Figure 4 shows the six sampling localities grouped into two clusters, one comprising Balcobo, Arousa, and the Isle of Batz and the other with Yerseke, Isle of Man, and Öland Island. These two major groups of individuals can also be observed in a PCA displayed on a twodimensional plot (Fig. 5). 
Figure 4. Unrooted NJ tree based on corrected Nei and Li distances as in Kostia et al. (2000)

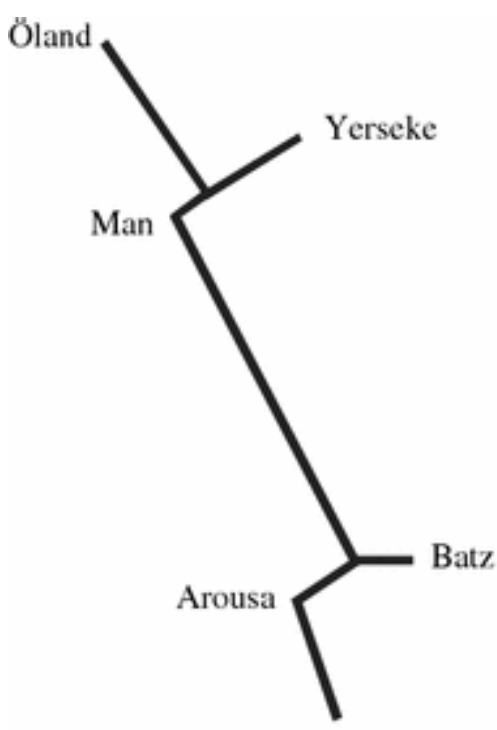

Balcobo

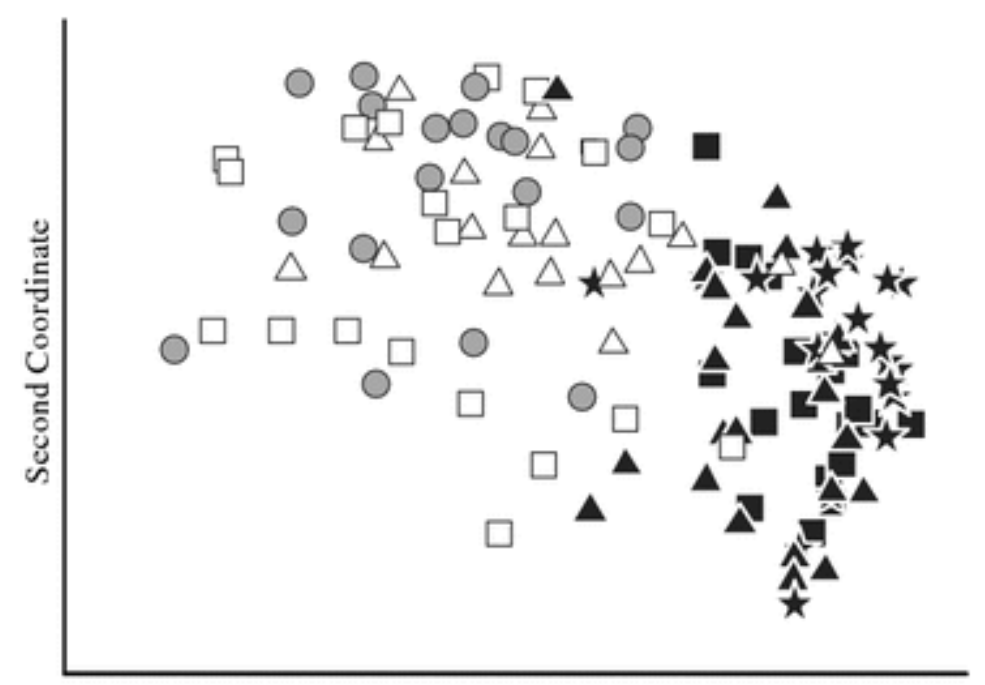

First Coordinate
Figure 5. Principal coordinates analysis based on Nei and Li distances using 21 ISSR markers from 120 individuals. The percentage of total variance of each axis was $29.0 \%$ for the first axis and $12.6 \%$ for the second axis. $\star$, Balcobo $(n=22) ; \mathbf{\square}$, Arousa $(n=19) ; \Delta$, Isle of Batz $(n=22) ; \square$, Yerseke $(n=20) ; \Delta$, Isle of Man $(n=18) ; \underline{\underline{0}}$, Öland Island $(n=19)$

Fifty-one ISSR markers of M. galloprovincialis mussels from Balcobo were chosen randomly, cloned, and sequenced. The sequences were analyzed with the program Tandem Repeats Finder 2.02 (TRF) (Benson 1999), which found 148 microsatellites. Microsatellites were found at the 3 ' and $5^{\prime}$ ends of each clone and 46 at internal positions (Table 2). Oligo 6.3 (Molecular Biology Insights) was used for designing primers to amplify the seven internal microsatellites with sufficient flanking sequence and more than five repeats. The Agilent 2100 Electrophoresis Bioanalyzer revealed the number of heterozygotes efficiently, allowing us to discard microsatellite loci with low polymorphism. Nevertheless, we detected an error in sizing fragments of approximately $5 \%$ between different runs of the same PCR reaction, similar to that described by Hierro et al. (2004); therefore, range sizes of alleles should be considered approximations. A sample of 22 M. galloprovincialis from Balcobo was analyzed. The results for the four primer pairs that yielded amplification products are shown in Table 3. One proved to be monomorphic ( $M g 192)$, and another ( $M g 272)$ generated too many nonspecific bands and was judged unacceptable for analysis. Two microsatellites (Mgl81 and $M g 220$ ) generated scorable and polymorphic products. Observed heterozygosities at $M g 181$ and $M g 220$ were 0.76 and 0.78 , respectively. 
Table 2. Description of the microsatellites found in 51 ISSR markers

\begin{tabular}{|c|c|c|c|}
\hline ISSR primer $^{\mathrm{a}}$ & Size & Repetitive motifs found along the sequence $^{b}$ & Accession no. \\
\hline \multirow[t]{3}{*}{$\mathrm{YG}(\mathrm{CA})_{9}$} & 681 & $(\mathrm{CA})_{9}(\mathrm{ATTT})_{5}(\mathrm{TA})_{7}(\mathrm{TG})_{12}$ & AJ938137 \\
\hline & 347 & $(\mathrm{AC})_{17}(\mathrm{CAAC})_{3}(\mathrm{CAAT})_{3}(\mathrm{CA})_{19}(\mathrm{TG})_{10}$ & AJ938136 \\
\hline & 236 & $(\mathrm{CA})_{9}(\mathrm{AT})_{5}(\mathrm{TG})_{51}$ & AJ938135 \\
\hline \multirow[t]{5}{*}{$\mathrm{YG}(\mathrm{GA})_{9}$} & 629 & $(\mathrm{GA})_{10}(\mathrm{GTCC})_{7}(\mathrm{TC})_{9}$ & AJ938134 \\
\hline & 622 & $(\mathrm{GA})_{9}(\mathrm{TC})_{5}(\mathrm{TC})_{9}$ & AJ938133 \\
\hline & 573 & $(\mathrm{GA})_{13}(\mathrm{TC})_{9}$ & AJ938132 \\
\hline & 432 & $(\mathrm{GA})_{9}(\mathrm{TC})_{5}(\mathrm{TC})_{9}(\mathrm{TC})_{9}(\mathrm{TC})_{9}$ & AJ938131 \\
\hline & 393 & $(\mathrm{GA})_{9}(\mathrm{TC})_{9}(\mathrm{TC})_{5}(\mathrm{CT})_{27}$ & AJ938130 \\
\hline \multirow[t]{4}{*}{ GATC(TCTG) $)_{8}$} & 775 & $(\mathrm{TCTG})_{8}(\mathrm{TCCG})_{4}(\mathrm{ACAG})_{8}$ & AJ938129 \\
\hline & 680 & $(\mathrm{TCTG})_{8}(\mathrm{CGGA})_{4}(\mathrm{ACAG})_{7}$ & AJ938128 \\
\hline & 570 & $(\mathrm{TCTG})_{8}(\mathrm{CAGA})_{8}$ & AJ938127 \\
\hline & 415 & $(\mathrm{TCTG})_{8}(\mathrm{CAGA})_{10}$ & AJ938126 \\
\hline \multirow[t]{9}{*}{$\operatorname{GATC}(\mathrm{CGT})_{7}$} & 744 & $(\mathrm{CGT})_{9}(\mathrm{GAC})_{7}$ & AJ938125 \\
\hline & 729 & $(\mathrm{CGT})_{8}(\mathrm{GAC})_{7}$ & AJ938124 \\
\hline & 729 & $(\mathrm{CGT})_{8}(\mathrm{GAC})_{7}$ & AJ938124 \\
\hline & 617 & $(\mathrm{CGT})_{7}(\mathrm{ACG})_{7}$ & AJ938123 \\
\hline & 483 & $(\mathrm{CGT})_{11}(\mathrm{ACG})_{10}$ & AJ938122 \\
\hline & 457 & $(\mathrm{CGT})_{12}(\mathrm{ACG})_{7}$ & AJ938121 \\
\hline & 407 & $(\mathrm{CGT})_{7}(\mathrm{ACG})_{6}$ & AJ938120 \\
\hline & 157 & $(\mathrm{CGT})_{9}(\mathrm{ACG})_{4}(\mathrm{GAT})_{4}(\mathrm{ACG})_{7}$ & AJ938119 \\
\hline & 149 & $(\mathrm{CGT})_{15}(\mathrm{ACG})_{7}$ & AJ938118 \\
\hline \multirow[t]{6}{*}{$\mathrm{YG}(\mathrm{CT})_{9}$} & 628 & $(\mathrm{CT})_{9}(\mathrm{AG})_{11}$ & AJ938117 \\
\hline & 564 & $(\mathrm{CT})_{9}(\mathrm{GA})_{9}$ & AJ938116 \\
\hline & 554 & $(\mathrm{CT})_{10}(\mathrm{TTCT})_{4}(\mathrm{AG})_{5}(\mathrm{GA})_{5}(\mathrm{AG})_{18}$ & AJ938115 \\
\hline & 471 & $(\mathrm{CT})_{9}(\mathrm{GA})_{9}$ & AJ938114 \\
\hline & 334 & $(\mathrm{CT})_{9}(\mathrm{GA})_{5}(\mathrm{GA})_{9}$ & AJ938113 \\
\hline & 252 & $(\mathrm{CT})_{10}(\mathrm{AG})_{5}(\mathrm{AG})_{9}$ & AJ938112 \\
\hline \multirow[t]{10}{*}{$\mathrm{KRV}(\mathrm{CT})_{6}$} & 715 & $(\mathrm{CT})_{6}(\mathrm{GA})_{6}$ & AJ938111 \\
\hline & 650 & $(\mathrm{CT})_{8}(\mathrm{GA})_{6}$ & AJ938110 \\
\hline & 564 & $(\mathrm{CT})_{11}(\mathrm{TTG})_{5}(\mathrm{AG})_{6}$ & AJ938109 \\
\hline & 498 & $\begin{array}{llll}(\mathrm{CT})_{7} & (\mathrm{CTTTTA})_{6}(\mathrm{AGTGAG})_{3}(\mathrm{GA})_{5}(\mathrm{GA})_{24}(\mathrm{GT})_{6} \\
(\mathrm{GA})_{6} & \end{array}$ & AJ938108 \\
\hline & 433 & $(\mathrm{CT})_{6}(\mathrm{GA})_{6}$ & AJ938107 \\
\hline & 343 & $(\mathrm{CT})_{6}(\mathrm{CT})_{5}(\mathrm{AG})_{8}$ & AJ938106 \\
\hline & 274 & $(\mathrm{CT})_{6}(\mathrm{AC})_{5}(\mathrm{GA})_{11}$ & AJ938105 \\
\hline & 206 & $(\mathrm{CT})_{6}(\mathrm{AGAA})_{3}(\mathrm{ATCG})_{5}(\mathrm{GA})_{5}(\mathrm{AG})_{6}$ & AJ938104 \\
\hline & 173 & $(\mathrm{CT})_{14}(\mathrm{TCTT})_{3}(\mathrm{AG})_{6}$ & AJ938103 \\
\hline & 167 & $(\mathrm{CT})_{9}(\mathrm{TCGA})_{3}(\mathrm{TCTT})_{3}(\mathrm{AG})_{6}$ & AJ938102 \\
\hline \multirow[t]{5}{*}{$\mathrm{HVH}(\mathrm{TTCG})_{4}$} & 736 & $(\mathrm{TTCG})_{4}(\mathrm{ACGA})_{10}$ & AJ938101 \\
\hline & 655 & $(\mathrm{TTCG})_{4}(\mathrm{CGAA})_{4}$ & AJ938100 \\
\hline & 506 & $(\mathrm{TTCG})_{6}(\mathrm{CGTC})_{8}(\mathrm{ACGA})_{4}$ & AJ938099 \\
\hline & 465 & $(\mathrm{TTCG})_{15}(\mathrm{CGTC})_{5}(\mathrm{ACGA})_{4}$ & AJ938098 \\
\hline & 333 & $(\mathrm{TTCG})_{6}(\mathrm{AT})_{5}(\mathrm{AACG})_{4}$ & AJ938097 \\
\hline
\end{tabular}




$\begin{array}{lllr} & 288 & (\mathrm{TTCG})_{7}(\mathrm{ACGA})_{4} & \text { AJ938096 } \\ & 193 & (\mathrm{TTCG})_{4}(\mathrm{ACGA})_{4} & \text { AJ938095 } \\ \text { HVG }(\mathrm{TG})_{7} & 312 & (\mathrm{GT})_{8}(\mathrm{CA})_{8} & \text { AJ938094 } \\ & 190 & (\mathrm{GT})_{8}(\mathrm{CA})_{7} & \text { AJ938093 } \\ \text { KKVRVRV }(\mathrm{CT})_{6} & 578 & (\mathrm{CT})_{6}(\mathrm{CT})_{10}(\mathrm{TCTCAC})_{13}(\mathrm{TCACTC})_{3}(\mathrm{TCACAT})_{7} & \\ & 404 & (\mathrm{AG})_{5}(\mathrm{GA})_{8} & \text { AJ938092 } \\ & 328 & (\mathrm{CT})_{6}(\mathrm{CT})_{6}(\mathrm{AG})_{9} & \text { AJ938091 } \\ & 269 & (\mathrm{CT})_{6}(\mathrm{CT})_{6}(\mathrm{AG})_{11} & \text { AJ938090 } \\ & 185 & (\mathrm{CT})_{6}(\mathrm{AG})_{7} & \text { AJ938089 } \\ & 148 & (\mathrm{CT})_{10}(\mathrm{GA})_{6} & \text { AJ938088 } \\ & & \text { AJ938087 }\end{array}$

${ }^{\mathrm{a}} \mathrm{Y}=\mathrm{C} / \mathrm{T}, \mathrm{K}=\mathrm{G} / \mathrm{T}, \mathrm{R}=\mathrm{A} / \mathrm{G}, \mathrm{V}=\mathrm{A} / \mathrm{C} / \mathrm{G}, \mathrm{H}=\mathrm{A} / \mathrm{C} / \mathrm{T}$

${ }^{\mathrm{b}}$ Core motifs of six or fewer nucleotides tandemly repeated at least three times

Table 3. Characterization of four microsatellite markers in the mussel Mytilus galloprovincialis

\begin{tabular}{|c|c|c|c|c|c|c|}
\hline Locus & EMBLEM no. & Repeat motif & $T_{a}$ & Primer sequence (5'-3') & $\boldsymbol{H}_{o}$ & Comments \\
\hline $\operatorname{Mg} 181$ & AJ938098 & $(\mathrm{CGTC}) 5$ & 56 & F: CTGCTTCAGGTTTTATGTCC & 0.7727 & Polymorphic \\
\hline $\operatorname{Mg} 192$ & AJ938136 & $(\mathrm{CA})_{19 \mathrm{i}}{ }^{\mathrm{a}}$ & 56 & $\begin{array}{l}\text { R: TCTGACAAATTGGCTTTTAAT } \\
\text { F: TGAGCACATCATCCTGAATA } \\
\text { R: CCACACACATGCAATGATAT }\end{array}$ & 0 & Monomorphic \\
\hline $\operatorname{Mg} 220$ & AJ938108 & $(\mathrm{GA})_{24}$ & 56 & $\begin{array}{l}\text { F: CCATGCTAGTATGAGGGTGCTAGTG } \\
\text { R: CTAACACTCTCTCACACAACGGCAT }\end{array}$ & 0.4545 & Polymorphic \\
\hline $\operatorname{Mg} 272$ & AJ938130 & $(\mathrm{TC})_{9} \ldots(\mathrm{TC})_{5}$ & 58 & $\begin{array}{l}\text { F: CCTCTAACACTAGGCCTCACCT } \\
\text { R: AGTGCCAGTGTGAGAGTGTGAG }\end{array}$ & - & Unscorable \\
\hline
\end{tabular}

Note: $T a$, annealing temperature; $H o$, observed heterozygosity

${ }^{\mathrm{a}}$ Imperfect tandem repeats

\section{Discussion}

\section{$\underline{\text { Assessment of Genetic Differentiation }}$}

Due to the widespread distribution of microsatellites in eukaryotic genomes, the amplification of ISSR markers does not require previous knowledge of the sequence that is to be analyzed. Nevertheless, the potential of the technique depends on the variety and frequency of microsatellites, which show considerable variance among species (Dieringer and Schlötterer 2003). This study provides evidence for the usefulness of ISSR markers to analyze genetic variability in Mytilus.

Inter-simple sequence repeat markers showed high genetic variation in Mytilus. In large populations, the probability of fixation or loss of alleles caused by genetic drift is more reduced than in small populations. Therefore, assuming mutation-drift equilibrium in ISSR markers and the intrinsic instability of microsatellite-rich sequences, the large populations of mussels accumulate neutral variants, maintaining high genetic diversity.

The variability revealed by ISSR markers identified each individual as a different haplotype. The detection of numerous polymorphic bands that provide information about several loci simultaneously indicates that this technique could be useful to define parentage and relatedness in mussels. Individual identification can provide a direct estimate of differential reproductive success of a group of individuals in a hatchery. 
Variance in reproductive success has been detected in molluscs (Hedgecock 1994) and produces a progeny that does not maintain the genetic composition of the broodstock. This reduction in genetic variability would make a selective breeding program difficult, and both ISSR markers and the Rp index as a primer choice criterion to assess identification and parentage relations could help to monitor this phenomenon.

The analysis of genetic differentiation among sampling localities using Nei and Li distances and the AMOVA grouped individuals into two clusters. One included Balcobo, Arousa, and Isle of Batz and the other Yerseke, Isle of Man, and Öland Island. This separation of individuals into two groups, however, was not well-defined (Fig. 5). This distribution could be explained by gene flow, cohabitation, or hybridization of two species in the same place.

The existence of the hybrids $M$. edulis $\times$ M. galloprovincialis and M. edulis $\times$ M. trossulus has been extensively reported and led some authors to consider these taxa as ecotypes of M. edulis (Gosling 1992). For example, the Atlantic coast of France and the British Isles are hybrid zones with contiguous regions rich in either M. galloprovincialis or M. edulis and where hybrids are also present. The grouping of the Isle of Batz with Arousa and Balcobo, identified as pure M. galloprovincialis by allozymes and morphometry (Sanjuan et al. 1990), indicates that the samples from the Isle of Batz could be located in a $M$. galloprovincialis-rich region. Notably, the marker that differentiates Arousa and Balcobo better from the pure M. edulis locality of Yerseke (Hummel et al. 2001), a $250 \mathrm{bp}$ band amplified by primer ISSR-23, is fixed in the Isle of Batz. On the other hand, our data suggest that the Isle of Man is in a M. edulis-rich zone, as this sample groups with Yerseke. Besides, the PCA did not separate individuals from the Baltic Sea and the mussels originated from Yerseke and Isle of Man. According to allozyme data, the distribution of $M$. edulis in Europe spreads from the Vizcaya Gulf to the north of the Polar Arctic Circle, but M. trossulus is confined in the Baltic Sea (Varvio et al. 1988). Analyses of nuclear (Borsa et al. 1999; Riginos et al. 2002) and mitochondrial markers (Wenne and Skibinski 1995) in mussels from the Baltic Sea, however, have revealed a high introgression of $M$. edulis alleles in Baltic Sea mussels. This high introgression seems to be strong enough in Öland Island to cluster this locality together with M. edulis, although the species M. edulis and M. galloprovincialis are more closely related (Rawson and Hilbish 1995, 1998; Hoeh et al. 1997; Hilbish et al. 2000).

\section{Characterization of Microsatellites}

Sequence analysis of 51 ISSR markers revealed that each sequence contained a microsatellite at both ends of the insert and many of them also had internal ones. The presence of these additional sequences in Mytilus supports the hypothesis previously reported in other organisms, in agreement with the clustering of microsatellites in some genomic regions (Schlötterer 2000).

High inherent instability and codominance make microsatellites extremely useful as genetic markers. In view of the microsatellites found in ISSR markers, sequencing of ISSR markers provides data that can be used to amplify single microsatellite loci. In previous studies on molluscs, microsatellites have been isolated from genomic libraries, and then these sequences have been useful in natural populations (Astanei et al. 2005) or as a tool of parentage identification (Walker et al. 2005). The development of microsatellite markers is a long and expensive process, however, and so some researchers examine the applicability of markers from related species (Evans et al. 2001). The success of these studies is clearly related to phylogenetic distance between species. Furthermore, few loci are available in mussel-related species, hence the isolation and characterization of microsatellite markers from the sequences amplified by anchored primers represents a feasible alternative as described previously (Fisher et al. 1996; Keiper et al. 2006; Varela et al. 2007). 
In summary, samples coming from the Isle of Man and the Isle of Batz, located in the M. edulis $\times$ M. galloprovincialis hybrid zone in Western Europe, proved to be rich in M. edulis and M. galloprovincialis, respectively. The mussels of Öland Island were not significantly different from a pure M. edulis locality (Yerseke), suggesting a high introgression of alleles of M. edulis in these individuals. ISSR markers detected high variability within each sampling locality and low genetic structuring within each member of the Mytilus edulis complex from the Atlantic European coast. This technique provided a fast and cost-effective analysis of polymorphism in a group of individuals, and at the same time, sequence data were gathered to perform more studies using single microsatellite loci.

\section{Acknowledgments}

We are grateful to Prof. Dennis Hedgecock for constructive comments on an earlier version of the manuscript and to Dr. H. Hummel, Dr. L. E. Persson, and ANFACO-CECOPESCA for kindly supplying the mussel specimens. M.V. was awarded a predoctoral fellowship from Xunta de Galicia. This research was supported by a grant (PGIDT10PX110304PR) from Xunta de Galicia.

\section{References}

Astanei I, Gosling E, Wilson J, Powell E (2005) Genetic variability and phylogeography of the invasive zebra mussel, Dreissena polymorpha (Pallas). Mol Ecol 14:1655-1666

Benson G (1999) Tandem repeats finder: a program to analyze DNA sequences. Nucleic Acids Res 27:573-580

Bierne N, Borsa P, Daguin C, Jollivet D, Viard F, Bonhomme F, David P (2003) Introgression patterns in the mosaic hybrid zone between Mytilus edulis and M. galloprovincialis. Mol Ecol 12:447-461

Black WC IV (1998) Fortran programs for the analysis of RAPD-PCR markers in populations. Colorado State University, Fort Collins

Borsa P, Daguin C, Ramos-Caetano S, Bonhomme F (1999) Nuclear-DNA evidence that northeast Atlantic Mytilus trossulus mussels carry M. edulis genes. J Moll Stud 65:504-507

Casu M, Maltagliati F, Cossu P, Lai T, Curini-Galletti M, Castelli A, Commito JA (2005) Finegrained spatial genetic structure in the bivalve Gemma gemma from Maine and Virginia (USA), as revealed by inter-simple sequence repeat markers. J Exp Mar Biol Ecol 325:4654

Dieringer D, Schlötterer C (2003) Two distinct modes of microsatellite mutation processes: evidence from the complete genomic sequences of nine species. Genome Res 13:2242-2251

Don RH, Cox PT, Wainwright BJ, Baker K, Mattick JS (1991) Touchdown PCR to circumvent spurious priming during gene amplification. Nucleic Acids Res 19:4008

Evans B, Conod N, Elliot NG (2001) Evaluation of microsatellite primer conservation in abalone. J Shell Res 20:1065-1070

Felsenstein, J (1993) Phylogeny Inference Package, Version 3.5C. University of Washington, Seattle

Fisher PJ, Gardner RC, Richardson TE (1996) Single locus microsatellites isolated using 5' anchored PCR. Nucleic Acids Res 24:4369-4371

Gosling EM (1992) Systematics and geographic distribution of Mytilus. In: Gosling EM (ed) The mussel Mytilus: ecology, physiology, genetics and culture. Elsevier, Amsterdam, pp 1-20

Hassan M, Harmelin-Vivien M, Bonhomme F (2003) Lessepsian invasion without bottleneck: example of two rabbitfish species (Siganus rivulatus and Siganus luridus). J Exp Mar Biol Ecol 291:219-232 
Hedgecock D (1994) Does variance in reproductive success limit effective population sizes of marine organisms? In: Beaumont AR (ed) Genetics and evolution of aquatic organisms. Chapman and Hall, London, pp 122-134

Hierro N, González A, Mas A, Guillamón JM (2004) New PCR-based methods for yeast identification. J Appl Microbiol 97:792-801

Hilbish TJ, Mullinax A, Dolven SI, Meyer RK, Koehn RK, Rawson PD (2000) Origin of the antitropical distribution pattern in marine mussels (Mytilus spp.): routes and timing of transequatorial migration. Mar Biol 136:69-77

Hoeh WR, Stewart DT, Saavedra C, Sutherland BW, Zouros E (1997) Phylogenetic evidence for role-associated mitochondrial DNA in Mytilus (Bivalvia: Mytilidae). Mol Biol Evol 14:959967

Hummel H, Colucci F, Bogaards RH, Strelkov P (2001) Genetic traits in the bivalve Mytilus from Europe with an emphasis on Artic populations. Polar Biol 24:44-52

Keiper FJ, Hayden MJ, Wallwork H (2006) Development of sequence tagged microsatellites (STMs) for the barley scald pathogen Rhynchosporium secalis. Mol Ecol Notes 6:543-546

Koehn RK (1991) The genetics and taxonomy of species in the genus Mytilus. Aquaculture 94:125-145

Kostia S, Ruohonen-Lehto M, Väinölä R, Varvio SL (2000) Phylogenetic information in interSINE and inter-SSR fingerprints of the artiodactyla and evolution of the Bov-tA SINE. Heredity 84:37-45

Nei M, Li WH (1979) Mathematical model for studying genetic variation in terms of restriction endonucleases. Proc Natl Acad Sci U S A 76:5269-5273

Palumbi SR (1994) Genetic divergence, reproductive isolation, and marine speciation. Annu Rev Ecol Syst 25:547-572

Panaro NJ, Yuen PK, Sakazume T, Fortina P, Kricka LJ, Widing P (2000) Evaluation of DNA fragment sizing and quantification by the Agilent 2100 Bioanalyzer. Clin Chem 46:18511853

Prevost A, Wilkinson MJ (1999) A new system of comparing PCR primers applied to ISSR fingerprinting to potato cultivars. Theor Appl Genet 98:107-112

Rawson PD, Hilbish TJ (1995) Evolutionary relationships among the male and female mitochondrial DNA linages in the Mytilus edulis species complex. Mol Biol Evol 12:893901

Rawson PD, Hilbish TJ (1998) Asymmetric introgression of mitochondrial DNA among European populations of blue mussels (Mytilus spp.). Evolution 52:100-108

Riginos C, Cunningham CW (2005) Local adaptation and species segregation in two mussel (Mytilus edulis $\times$ Mytilus trossulus) hybrid zones. Mol Ecol 14:381-400

Riginos C, Sukhdeo K, Cunningham CW (2002) Evidence for selection at multiple allozyme loci across a mussel hybrid zone. Mol Biol Evol 19:347-351

Sanjuan A, Quesada H, Zapata C, Alvarez G (1990) On the occurrence of Mytilus galloprovincialis Lmk. on the Iberian Peninsula. J Exp Mar Biol Ecol 143:1-15

Schlötterer C (2000) Evolutionary dynamics of microsatellite DNA. Chromosoma 109:365-371

Schneider S, Roessli D, Excoffier L (2000) Arlequin ver. 2000: a software for population genetics data analysis. Genetics and Biometry Laboratory, University of Geneva, Switzerland

SPSS Inc (1999) SPSS 10.0.6 for Windows, Chicago, IL

Varela MA, González-Tizón A, Francisco-Candeira M, Martínez-Lage A (2007) Isolation and characterization of polymorphic microsatellite loci in the razor clam Ensis siliqua. Mol Ecol Notes 7:221-222

Varvio SL, Koehn RK, Väinölä R (1988) Evolutionary genetics of the Mytilus edulis complex in the North Atlantic region. Mar Biol 98:51-60

Walker D, Power AJ, Avise JC (2005) Sex-linked markers facilitate genetic parentage analyses in knobbed whelk broods. J Hered 96:108-113 
Wenne R, Skibinski DOF (1995) Mitochondrial DNA heteroplasmy in European populations of the mussel Mytilus trossulus. Mar Biol 122:619-625

Winnepenninck B, Backeljau T, De Wachter R (1993) Extraction of high molecular weight DNA from molluscs. Trends Genet 9:407

Zietkiewicz E, Rafalski A, Labuda D (1994) Genome fingerprinting by simple sequence repeat (SSR)-anchored polymerase chain reaction amplification. Genomics 20:176-183

\footnotetext{
i This is a post-peer-review, pre-copyedit version of an article published in [Biochemical Genetics]. The final authenticated version is available online at: [https://doi.org/10.1007/s10528-007-9097-7].

ii andres@udc.es
} 